\title{
The relationship between phosphorus level and peak oxygen uptake in hemodialysis patients awaited for renal transplantation
}

\author{
Boshra Hasanzamani $^{1}{ }^{\circledR}$, Mohamad Javad Mojahedi ${ }^{1}$, Saba Khajeh Dargi ${ }^{2}$, Amir Mohamad Hashem \\ Asnaashari ${ }^{*} \mathbb{D}$ \\ ${ }^{1}$ Kidney Transplantation Complications Research Center, Department of Internal Medicine, Ghaem Hospital, School of Medicine, \\ Mashhad University of Medical Sciences, Mashhad, Iran \\ ${ }^{2}$ Mashhad University of Medical Sciences, Mashhad, Iran
}

\section{A R T I C L E I N F 0}

\section{Article Type:}

Original

\section{Article History:}

Received: 8 August 2019

Accepted: 12 November 2019

Published online: 4 December 2019

\section{Keywords:}

End-stage renal disease

Phosphorus

Maximal oxygen uptake

Renal transplantation

Chronic kidney disease

\begin{abstract}
A B S T R A C T
Introduction: End-stage renal disease (ESRD) is one of the most common diseases, which affects many aspects of patients' lives. The measurement of exercise capacity through peak oxygen uptake is an important factor in predicting mortality and survival in patients with ESRD. Objectives: In the current study, we aimed to examine the relationship between phosphorus level and $\mathrm{VO}_{2}$ uptake in renal transplant candidates receiving hemodialysis.

Patients and Methods: Thirty renal transplant candidates on hemodialysis were evaluated through spirometry and exercise tests. Then, the results were compared according to the inclusion criteria of age, gender, and phosphorus level.

Results: All of cases were male with the mean age of $37.93 \pm 10.48$ years (range; $20-55$ years). Mean $\mathrm{VO}_{2}$ max was $23.46 \pm 8.22 \mathrm{~mL} / \mathrm{kg} / \mathrm{min}$ (range; 6.88 to $43.44 \mathrm{~mL} / \mathrm{kg} / \mathrm{min}$ ). The mean phosphorus level was $6 \pm 2.3 \mathrm{mg} / \mathrm{dL}$ (range; $2-10.6 \mathrm{mg} / \mathrm{dL}$ ) since eight patients had high levels of phosphorus (more than $5.5 \mathrm{mg} / \mathrm{dL}$ ). In patients with low phosphorus level an abnormal $\mathrm{VO}_{2}$ max was detected $(P=0.027)$. Furthermore, Fisher's exact test reflected a significant association between higher levels of phosphorus with normal $\mathrm{VO}_{2} \max (P=0.029)$.

Conclusion: In hemodialysis, decreased blood phosphorus is a predisposing factor for reduced exercise capacity, while hypophosphatemia may lower $\mathrm{VO}_{2}$ max through reducing energy of skeletal muscles. The relationship between phosphorus level and $\mathrm{VO}_{2}$ max may be related to morbidity in hemodialysis patients. Hence, treatment modalities reducing serum levels of phosphorus should be conducted with caution in some patients.
\end{abstract}

Implication for health policy/practice/research/medical education:

In a study on 30 ESRD patients awaiting renal transplantation, we found, decreased blood phosphorus is a predisposing factor for decreased exercise capacity, while hypophosphatemia may lower maximal oxygen uptake $\left(\mathrm{VO}_{2}\right.$ max) through reducing energy of skeletal muscles. In fact, ideal control of phosphate level in CKD is important to avoid complications of secondary hyperparathyroidism. Nevertheless, too low phosphate level may present a risk for disturbed pulmonary function and exercise capacity.

Please cite this paper as: Hasanzamani B, Mojahedi MJ, Khajeh Dargi S, Asnaashari AMH. The relationship between phosphorus level and peak oxygen uptake in hemodialysis patients awaited for renal transplantation. J Renal Inj Prev. 2020; 9(1): e05. doi: 10.15171/jrip.2020.05.

\section{Introduction}

End-stage renal disease (ESRD) is the final stage of chronic kidney disease (CKD), in which the kidneys no longer function well enough to meet the needs of daily life $(1,2)$. The treatments for ESRD are dialysis or kidney transplant $(3,4)$. The worldwide rise in the number of patients with CKD and its consequent named end-stage renal failure need renal replacement therapy (5). Although the improvement in survival of patients undergoing maintenance dialysis in the United States is detectable, however, mortality continues to be unacceptably high, approaching 20\% per year (6-9).

Functional capacity of ESRD patients is dramatically impaired, since CKD patients treated with dialysis are characterized by a severely limited exercise capacity $(10,11)$.

Maximal oxygen uptake $\left(\mathrm{VO}_{2} \mathrm{max}\right)$ is a predictor of postoperative mortality. Maximal oxygen uptake level 
in $\mathrm{CKD}$ is $59.3 \%$ of the age-predicted $\mathrm{VO}_{2}$ max level in normal controls (12). In fact, low $\mathrm{VO}_{2}$ and self-reported functioning were shown to be predictive of poor outcomes in dialysis patients (13). Contributing factors include hypertension, glucose intolerance, dyslipidemia, high serum homocysteine concentrations, and abnormalities in calcium and phosphorus metabolism (14). Many of these disturbances are present in children and young adults with ESRD. Phosphorus, as an important mineral for cell structure and energy, circulates less than $1 \%$ in the serum, the "exchangeable phosphorus pool" as suggested by Hruska et al (15). In normal subjects, the skeleton remains neutral (equal exit and entry) regarding phosphorus homeostasis and the kidneys regulate phosphorus balance $(16,17)$. In renal disease, the kidney fails to excrete phosphorus and the result is a positive phosphorus balance (18). Elevated serum phosphate is a common complication among ESRD patients, affecting up to $70 \%$ of dialysis patients $(19,20)$. Increased serum phosphorus level is associated with high mortality rate. In spite of dietary restrictions, individuals receiving dialysis invariably experience hyperphosphatemia (21). Dietary restriction of phosphorus and dialysis prescription are unable to maintain phosphorus level within the recommended range (below $5.5 \mathrm{mg} / \mathrm{dL}$ ) in patients with advanced ESRD.

\section{Objectives}

Given the paucity of studies on this issue and the importance of both phosphorus and $\mathrm{VO}_{2}$ max in ESRD, we aimed to assess the relationship between phosphorus level and $\mathrm{VO}_{2}$ uptake in renal transplant candidates receiving hemodialysis therapy.

\section{Patients and Methods}

\section{Study population}

We studied 30 patients with chronic renal failure. We performed pulmonary function testing (PFT) and cardiopulmonary exercise test (CPET) for all the subjects. The main inclusion criterion was the stability of patients for performing the exercise test. The exclusion criteria comprised of active infectious and inflammatory diseases, malignancy, malnutrition, atopy and asthma, history of myocardial infarction, walking disability, arthritis and arthralgia, disability and exertion-limiting cardiac diseases.

\section{Laboratory assessments}

Venous blood samples were collected to measure the level of serum phosphorus. We considered other factors that might limit exercise capacity. Symptom-limited or maximal-heart-rate testing (CPET) was conducted by a cycle ergometer (ergo-metrics 900, SensorMedics, Bilthoven, The Netherlands) and a spirometer. Patients were advised not to eat or drink several hours before exercise testing. The gas analyzer was calibrated just before the investigation. A facemask connected to a lowresistance unidirectional valve was placed on the patients' face and checked for leakage. The incremental exercise test consisted of a 3-minute baseline resting period, followed by a 3-minute warm-up period (up to $60 \mathrm{rpm}$ pedaling), and subsequent periodic work increased by 15 watts each minute. For each patient, during ECG testing, blood pressure and oxygen saturation were regularly monitored. When the heart rate reaches a maximum level or the exercise-limiting signs are observed, then the ECG was stopped.

\section{Ethical issues}

The research followed the tenets of the Declaration of Helsinki. Informed consent was obtained. The ethical committee of Mashhad University of Medical Sciences approved the research (Ref \#98/94073). All patients' information remained confidential. This study was extracted from M.D thesis of Saba Khajeh Dargi (Thesis \#6812) and supported by the Kidney Transplantation Complications Research Center, Mashhad University of Medical Sciences, Mashhad, Iran

\section{Statistical analysis}

The normality of data was tested by using KolmogorovSmirnov test. Parametric variables were extracted as mean \pm standard deviation (SD). Categorical data were stated as percent and compared by Fisher's exact test. T-test was used to compare differences between groups. The data were analyzed by SPSS version 16. The Pearson's correlation test was used to evaluate the relationship between serum phosphorus and $\mathrm{VO}_{2}$ max. In this study, $P$ values below 0.05 were considered as statistically significant for all tests.

Results

All patients were male with the mean age of $37.93 \pm 10.48$ years (age range; 20-55 years). The $\mathrm{VO}_{2} \max$ was $23.46 \pm 8.22 \mathrm{ml} / \mathrm{kg} / \mathrm{min}$ (range; 43.44-6.88 $\mathrm{mL} / \mathrm{kg} / \mathrm{min}$ ). Maximum and minimum levels of phosphorus were 10.6 $\mathrm{mg} / \mathrm{dL}$ and $2 \mathrm{mg} / \mathrm{dL}$, respectively, with the mean level of $(6 \pm 2.3 \mathrm{mg} / \mathrm{dL})$.

Based on $\mathrm{VO}_{2}$ max, we divided all the cases into two groups of normal $(\geq 20 \mathrm{ml} / \mathrm{kg} / \mathrm{min})$ and abnormal $(<20$ $\mathrm{mL} / \mathrm{kg} / \mathrm{min}$ ).

Pearson's correlation analysis revealed a direct relationship between serum phosphorus level and VO2 uptake ( $r=0.71, P=0.02$; Figure 1 ). According to fisher's exact test, patients with low phosphorus levels presented abnormal $\mathrm{VO}_{2} \max (P=0.027$; Tables 1 and 2$)$.

\section{Discussion}

Reduced peak oxygen uptake (peak $\mathrm{VO}_{2}$ ) is a prognosticator of mortality in various chronic diseases during the preoperative period. Low peak $\mathrm{VO}_{2}$ in $\mathrm{CKD}$ patients can be due to different circumstances comprising, electrolyte imbalance, cardiovascular diseases, anemia, 


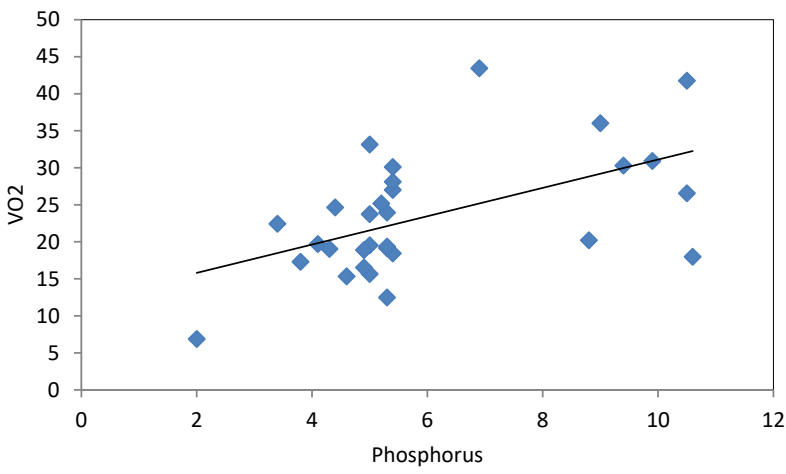

Figure 1. Association between phosphorus level and oxygen uptake $\left(\mathrm{VO}_{2}\right)$.

Table 1. Mean and standard deviation of demographic data, phosphorus, and oxygen uptake $\left(\mathrm{VO}_{2}\right)$

\begin{tabular}{lcc}
\hline Variable & Mean \pm SD & Range \\
\hline Age $(\mathrm{y})$ & $37.93 \pm 10.48$ & $(20-55)$ \\
Weight $(\mathrm{kg})$ & $65.23 \pm 14.78$ & $(43-101)$ \\
Phosphorus $(\mathrm{mg} / \mathrm{dL})$ & $6 \pm 2.31$ & $(2-10.6)$ \\
$\mathrm{VO}_{2} \max (\mathrm{mL} / \mathrm{kg} / \mathrm{min})$ & $23.46 \pm 8.22$ & $(6.88-43.44)$ \\
\hline
\end{tabular}

Table 2. Phosphorus level and maximal oxygen uptake $\left(\mathrm{VO}_{2} \mathrm{max}\right)$

\begin{tabular}{|c|c|c|c|}
\hline \multirow{2}{*}{ Phosphorus level } & \multicolumn{2}{|c|}{$\begin{array}{c}\text { Maximal oxygen uptake } \\
(\mathrm{mL} / \mathrm{kg} / \mathrm{min})\end{array}$} & \multirow{2}{*}{$P$ value } \\
\hline & $\begin{array}{c}<20 \\
\text { No. (\%) }\end{array}$ & $\begin{array}{c}\geq 20 \\
\text { No. (\%) }\end{array}$ & \\
\hline Нyро & $1(50)$ & $1(50)$ & \\
\hline Normal & $12(60)$ & $8(40)$ & 0.027 \\
\hline Hyper & $1(12.5)$ & 7 (87.5) & \\
\hline
\end{tabular}

malnutrition, active infections and hyperparathyroidism (22-25).

In this study, we found a significant relationship between low-serum phosphate level and decreased $\mathrm{VO}_{2}$. Various investigations have revealed that peak $\mathrm{VO}_{2}$ is a predictor of postoperative mortality $(26,27)$ in individuals with kidney insufficiency waiting for renal transplantation (13). Phosphorus is the main component of adenosine $5^{\prime}$-triphosphate (ATP) in energy-related mechanisms operating in muscles of the respiratory and musculoskeletal systems (28).

On the other hand, hyperphosphatemia is a serious problem due to secondary hyperparathyroidism in chronic renal failure patients. Phosphorus-binding agents are recommended to control serum phosphate level in these individuals $(29,30)$. Ulubay et al studied the factors affecting exercise capacity in renal transplantation candidates receiving continuous ambulatory peritoneal dialysis therapy (31). Correspondingly, they found that peak $\mathrm{VO}_{2}$ was well correlated with serum phosphate level. They found, $96 \%$ the patients terminated cardiopulmonary exercise testing due to tiredness in leg. They explained this mechanism of exercise limitation as peripheral and respiratory muscle weakness due to lowserum phosphorus level in individuals with ESRD.

Ideal control of phosphate level in CKD individuals is important to avoid complications of secondary hyperparathyroidism. Nevertheless, too low phosphate level may present a risk for disturbed pulmonary function and exercise capacity. Based on our findings, we conclude that treatment modalities that lower serum phosphorus level should be applied with caution in individuals with kidney insufficiency. High perioperative risk is an absolute contraindication for kidney transplantation. Peak oxygen uptake is a valuable interpreter of perioperative mortality. The results of this investigation suggest that parameters decreasing oxygen uptake (like phosphorus-binding agents that might lower serum phosphorus level) must be monitored closely and considered during the preoperative period in individuals with end-stage kidney insufficiency waiting for transplantation.

In our study, all the studied patients were candidate for renal transplantation. In a study to find, the consequence of kidney transplantation on pulmonary function and respiratory muscle strength in patients with end-stage kidney failure, Guleria et al showed that transplantation resulted in a significant improvement in pulmonary and respiratory muscle function (32). This may confirm our findings regarding the fact that decreased $\mathrm{VO}_{2}$ max diminished the energy of skeletal muscles. Development of new phosphate binders and efforts to find new ways to inhibit gastrointestinal absorption of phosphate might improve management of serum phosphate level in ESRD patients.

\section{Conclusion}

In renal transplant patients, elevated phosphorus level can be the sole predisposing factor for decreased exercise capacity. Hypophosphatemia may decrease the $\mathrm{VO}_{2}$ max by reducing energy of skeletal muscles. Regarding, the relationship between phosphorus and $\mathrm{VO}_{2}$ max, patients' survival can be enhanced in patients with ESRD awaiting renal transplantation. However, treatment modalities diminishing serum phosphorus level should be applied with caution in these patients.

\section{Limitations of the study}

This study was conducted on a limited proportion of patients. We suggest larger studies on this feature of hemodialysis patients.

Acknowledgments

We would like to thank all staff of spirometry and Sports Sciences Department of Ghaem Hospital, Mashhad University of Medical Sciences, and all those who have helped us in this study. 


\section{Authors' contribution}

$\mathrm{HB}, \mathrm{MM}, \mathrm{KS}$ and AA conducted the research. KS conducted the statistical analysis. HB prepared the primary draft. AA revised and prepared the final manuscript. All authors read and approved the final paper.

\section{Conflicts of interest}

There were no points of conflict to declare.

\section{Ethical considerations}

Ethical issues (including plagiarism, data fabrication, double publication) have been completely observed by the authors.

\section{Funding/Support}

This study was extracted from MD thesis of Saba Khajeh Dargi (\#6812) and supported by the Kidney Transplantation Complications Research Center, Mashhad University of Medical Sciences, Mashhad, Iran.

\section{References}

1. Levey AS, Stevens LA, Coresh J. Conceptual model of CKD: applications and implications. Am J Kidney Dis. 2009;53:S4-16. doi: 10.1053/j.ajkd.2008.07.048.

2. Rettig RA, Norris K, Nissenson AR. Chronic kidney disease in the United States: a public policy imperative. Clin J Am Soc Nephrol. 2008;3:1902-10. doi: 10.2215/CJN.02330508.

3. Grassmann A, Gioberge S, Moeller S, Brown G. ESRD patients in 2004: global overview of patient numbers, treatment modalities and associated trends. Nephrol Dial Transplant. 2005;20:2587-93. doi: 10.1093/ndt/gfi159

4. Lysaght MJ. Maintenance dialysis population dynamics: current trends and long-term implications. J Am Soc Nephrol. 2002;13:S37-S40.

5. El Nahas AM, Bello AK. Chronic kidney disease: the global challenge. Lancet. 2005;365:331-40. doi: 10.1016/S01406736(05)17789-7

6. Coresh J, Astor BC, Greene T, Eknoyan G, Levey AS. Prevalence of chronic kidney disease and decreased kidney function in the adult US population: Third National Health and Nutrition Examination Survey. Am J Kidney Dis. 2003;41:1-12.doi: 10.1053/ajkd.2003.50007

7. Coresh J, Selvin E, Stevens LA, Manzi J, Kusek JW, Eggers $\mathrm{P}$, et al. Prevalence of chronic kidney disease in the United States. JAMA. 2007;298:2038-47. doi: 10.1001/ jama.298.17.2038

8. Goldfarb-Rumyantzev A, Brown RS, Dong N, Sandhu GS, Vohra P, Gautam S. Developing and testing models to predict mortality in the general population. Inform Health Soc Care. 2019:1-16. doi: 10.1080/17538157.2019.1656209.

9. Horowitz B, Miskulin D, Zager P. Epidemiology of hypertension in CKD. Adv Chronic Kidney Dis. 2015; 22:88-95. doi: 10.1053/j.ackd.2014.09.004.

10. Konstantinidou E, Koukouvou G, Kouidi E, Deligiannis A, Tourkantonis A. Exercise training in patients with endstage renal disease on hemodialysis: comparison of three rehabilitation programs. J Rehabil Med. 2002;34:40-5. doi: 10.1080/165019702317242695

11. Moore GE, Brinker KR, Stray-Gundersen J, Mitchell JH.
Determinants of VO2peak in patients with end-stage renal disease: on and off dialysis. Med Sci Sports Exerc. 1993;25:18-23.

12. Padilla J, Krasnoff J, DaSilva M, Hsu C-Y, Frassetto L, Johansen KL, et al. Physical functioning in patients with chronic kidney disease. J Nephrol. 2008;21:550-9.

13. Sietsema KE, Amato A, Adler SG, Brass EP. Exercise capacity as a predictor of survival among ambulatory patients with end-stage renal disease. Kidney Int. 2004;65:719-24. doi: 10.1111/j.1523-1755.2004.00411.x

14. Goodman WG, Goldin J, Kuizon BD, Yoon C, Gales B, Sider D, et al. Coronary-artery calcification in young adults with end-stage renal disease who are undergoing dialysis. N Engl J Med. 2000;342:1478-83. doi: 10.1056/ NEJM200005183422003

15. Hruska KA, Mathew S, Lund R, Qiu P, Pratt R. Hyperphosphatemia of chronic kidney disease. Kidney Int. 2008;74:148-57. doi: 10.1038/ki.2008.130.

16. Giachelli CM. The emerging role of phosphate in vascular calcification. Kidney Int. 2009;75:890-7. doi: 10.1038/ ki.2008.644.

17. Spasovski G, Massy Z, Vanholder R. Phosphate metabolism in chronic kidney disease: from pathophysiology to clinical management. Semin Dial. 2009;22:357-62. doi: 10.1111/j.1525-139X.2009.00580.x.

18. Mathew S, Tustison KS, Sugatani T, Chaudhary LR, Rifas L, Hruska KA. The mechanism of phosphorus as a cardiovascular risk factor in CKD. J Am Soc Nephrol. 2008;19:1092-105. doi: 10.1681/ASN.2007070760.

19. Block GA, Hulbert-Shearon TE, Levin NW, Port FK. Association of serum phosphorus and calcium x phosphate product with mortality risk in chronic hemodialysis patients: a national study. Am J Kidney Dis. 1998;31:607-17.

20. Prajapati VA, Galani VJ, Shah PR. A comparative study of phosphate binders in patients with end stage kidney disease undergoing hemodialysis. Saudi J Kidney Dis Transpl. 2014;25:530. doi: 10.4103/1319-2442.132167

21. Tonelli M. Serum phosphorus in people with chronic kidney disease: you are what you eat. Kidney Int. 2013; 84:871-3. doi: 10.1038/ki.2013.258

22. Joborn C, Rastad J, Stålberg E, Åkerström G, Ljunghall S. Muscle function in patients with primary hyperparathyroidism. Muscle Nerve. 1989;12:87-94. doi: $10.1002 /$ mus. 880120202

23. Kristoffersson A, Boström A, Söderberg T. Muscle strength is improved after parathyroidectomy in patients with primary hyperparathyroidism. Br J Surg. 1992;79:165-8. doi: 10.1002/bjs.1800790223 .

24. McMahon LP, McKenna MJ, Sangkabutra T, et al. Physical performance and associated electrolyte changes after haemoglobin normalization: a comparative study in haemodialysis patients. Nephrol Dial Transplant. 1999;14:1182-7. doi: 10.1093/ndt/14.5.1182

25. Moreno F, Aracil FJ, Pérez R, Valderrábano F. Controlled study on the improvement of quality of life in elderly hemodialysis patients after correcting end-stage renal disease-related anemia with erythropoietin. Am J Kidney Dis. 1996;27:548-56. doi: 10.1016/S0272-6386(96)90166-3

26. Lund LH, Edwards LB, Kucheryavaya AY, et al. The Registry of the International Society for Heart and Lung 
Transplantation: Thirty-second Official Adult Heart Transplantation Report--2015; Focus Theme: Early Graft Failure. J Heart Lung Transplant. 2015;34:1264-77. doi:10.1016/j.healun.2015.08.014.

27. Older P, Hall A. Preoperative assessment of elderly surgical patients. Cardiopulmonary exercise testing and cardiovascular health . Crit Care Resusc. 2000;2:198-208.

28. Valsami-Jones E, Association IW. Phosphorus in environmental technologies: Principles and applications: IWA Publishing; 2004.

29. Emmett M. A comparison of clinically useful phosphorus binders for patients with chronic kidney failure. Kidney Int. 2004;66:S25-32. doi: 10.1111/j.1523-1755.2004.09005.x

30. Hartmut H. Malluche Hanna Mawad. Management of hyperphosphatasemia of chronic kidney disease: lessons from the past and future directions. Nephrol Dial Transplant. 2002:17:1170-5. doi: 10.1093/ndt/17.7.1170

31. Ulubay G, Akman B, Sezer S, Calik K, Eyuboglu Oner F, Ozdemir N, et al. Factors affecting exercise capacity in renal transplantation candidates on continuous ambulatory peritoneal dialysis therapy. Transplant Proc. 2006;38:401-5. doi: 10.1016/j.transproceed.2005.12.107

32. Guleria S, Agarwal RK, Guleria R, Bhowmik D, Agarwal SK, Tiwari SC. The effect of renal transplantation on pulmonary function and respiratory muscle strength in patients with end-stage renal disease. Transplant Proc. 2005;37:664-5. doi:10.1016/j.transproceed.2005.01.051

Copyright $\odot 2020$ The Author(s); Published by Nickan Research Institute. This is an open-access article distributed under the terms of the Creative Commons Attribution License (http://creativecommons.org/licenses/by/4.0), which permits unrestricted use, distribution, and reproduction in any medium, provided the original work is properly cited. 